Fordham Law School

FLASH: The Fordham Law Archive of Scholarship and History

Faculty Scholarship

2019

Centros and Defensive Regulatory Competition: Some Thoughts and a Glimpse at the Data

Martin Gelter

Follow this and additional works at: https://ir.lawnet.fordham.edu/faculty_scholarship

Part of the Law Commons 


\title{
Centros and Defensive Regulatory Competition: Some Thoughts and a Glimpse at the Data
}

\author{
MARTIN GELTER*
}

\begin{abstract}
This paper looks at the phenomenon of "defensive regulatory competition" in European corporate law following Centros, Überseering and Inspire Art. In order to retain control over the corporate governing private limited entities operating within their territories and to prevent the proliferation of "foreign limited" formations, Member States have modified some of the features of their laws that company founders considers most unattractive, such as minimum capital and time-consuming incorporation procedures. The first part of the paper analyzes the market for the law governing privately held firms, drawing from the debate in the United States. The US and Europe differ in that regulatory competition, as far as substantive law is concerned, focuses mainly on ex post mechanisms such as directors' duties and veil piercing. By contrast, European competition seems to be driven by ex ante issues relating to firm formation, such as minimum capital. The second part of the paper draws from an ongoing empirical research project that attempts to explore the effects of regulatory competition and uses reforms in Germany and Belgium as examples. Regression analysis suggests that at least the German 2008 reform had a minor effect on the number of UK private limited companies being set up to do business in Germany.
\end{abstract}

Keywords: Regulatory competition, insolvencification, regulatory arbitrage, Austria, Netherlands, Inspire Art

\section{Table of Contents}

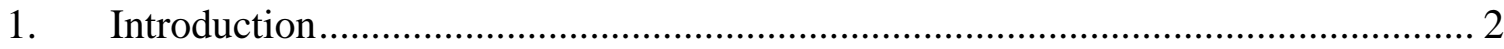

2. Privately held firms and regulatory competition ............................................... 3

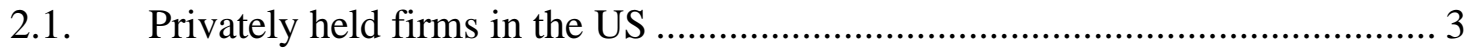

2.2. Competition for privately held firms in Europe ......................................... 8

2.3. Insolvencification and defensive regulatory competition............................. 13

3. Tackling the empirical effects of defensive regulatory competition ..................... 18

3.1. Centros as the object of empirical research............................................... 18

3.2. Constructing time series to capture the Centros phenomenon ........................ 19

3.3. Is defensive regulatory competition even necessary?.................................. 25

\footnotetext{
* Professor of Law, Fordham University School of Law, 150 West $62^{\text {nd }}$ Street, New York, NY 10023, USA. E-Mail: mgelter@law.fordham.edu; phone: (+1)646-312-8752. I thank participants of the $3^{\text {rd }}$ Annual OBLB conference, especially Steven Davidoff Solomon and Luca Enriques, for helpful comments on the larger research project on which this article is based.
} 
3.4. Exploring the impact of defensive regulatory competition .......................... 27

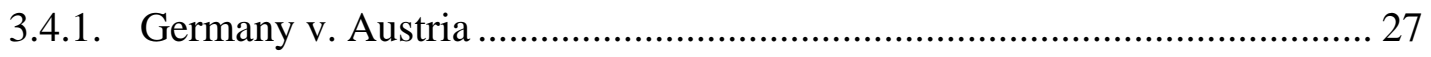

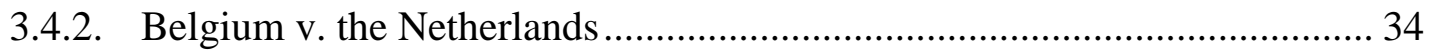

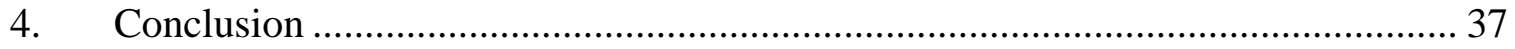

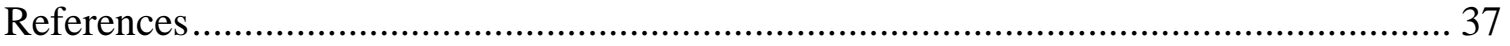

\section{Introduction}

Centros $^{1}$ and the cases following it had a profound transformational effect on European company law. While it has so far not resulted in fully-fledged regulatory competition for publicly traded companies (analogous to the situation in the United States), the case had at least two consequences. First, the discourse about EU Company Law, and about the national corporate law system, has become much more international. While the CJEU case law was not the only factor in this development, it likely contributed. ${ }^{2}$ Second, some member states have adjusted their laws to mitigate the effects of Centros. This article explores one reaction by some EU Member States, namely "defensive regulatory competition," ${ }^{3}$ which refers to the attempt to stop the "flow" of incorporation to other Member States by modifying the law.

This article provides a partial theoretical and empirical analysis of defensive regulatory competition. It compares the market for closely held corporations and LLCs in the United States United States with the European market for the law of privately limited companies, which led to a debate about regulatory competition and the legal capital system after Centros, Überseering ${ }^{4}$, and

${ }^{1}$ Centros Ltd v Erhvervs- og Selskabsstyrelsen, Case C-212/97 [1999] E.C.R. I-1459.

${ }^{2}$ Gelter 2017, p 332-333.

${ }^{3}$ E.g. Enriques and Gelter 2006, p 424; Enriques and Gelter 2007, p 600; Ringe 2013, p 243.

${ }^{4}$ Überseering BV v. Nordic Construction Company Baumanagement GmbH, Case C-208/00 [2002] ECR. I-9919. 
Inspire Art. ${ }^{5}$ I suggest that in Europe, the absence of a market for corporate law has meant that there were initially relatively low-hanging fruit to pick for regulatory competition, whereas the relatively limited US debate focuses on more subtle doctrinal issues (that likely impose smaller costs on founders). In its empirical part, this article draws from an empirical analysis developed in a companion paper. ${ }^{6}$ Using the examples of reforms in Germany and Belgium (for which Austrian and Dutch firm formations serve as control groups), I suggest that the reforms had a small but discernable impact at least in Germany. However, one could argue that the overall effects of Continental European firm formations in the UK were small, which raises questions about the justification of defensive regulatory competition.

Section 2 briefly surveys the debate about regulatory competition in the United States and compares it to the European debate. It also seeks to circumscribe the concept of "defensive regulatory competition,” which has been a major, if sometimes underappreciated element of the European development, and contrasts it with "insolvencification," the other response by some Member States. Section 3 seeks to tackle defensive regulatory competition empirically and seeks to quantify the extent of its effects. Section 4 summarizes and concludes.

\section{Privately held firms and regulatory competition}

\subsection{Privately held firms in the US}

The United States is the jurisdiction of reference for any study looking at regulatory competition in corporate law. The bulk of the literature there, however, deals with publicly traded

\footnotetext{
${ }^{5}$ Kamer van Koophandel en Fabrieken voor Amsterdam v. Inspire Art Ltd., Case C-167/01 [2003] ECR I-10155.

${ }^{6}$ Gelter (work in progress).
} 
firms, in part because these are the focus of academic interest in general, and because of the availability of data. ${ }^{7}$ By contrast, in Europe the practical impact of the free choice of incorporation has been constrained mainly to privately held firms, particularly private limited companies.

Incorporation choices are made only on occasion, either in the form of an initial incorporation in a particular state, or in the form of a reincorporation to another state, which is usually implemented through a merger in the US. ${ }^{8}$ For publicly traded corporations, where proxy disclosure requirements add considerable cost to a reincorporation, the capital market still sets some of the key incentives driving these choices. On the one hand, there are considerable information asymmetries between management (or, as the case may be, controlling shareholders) on the one hand, and dispersed investors on the other, which might lead to the conclusion that the market for corporate law will disfavor outside investors. On the other hand, market prices should in principle adjust to features of the chosen state corporate law that affect firm value, thus setting incentives to choose a value-maximizing corporate law.

It is not entirely clear whether US states actively compete for the incorporation of privately held business entities, or whether law-making activities in the field can be distinguished from the objective of creating a business-friendly environment. ${ }^{9}$ There are reasons to believe that state legislatures are little suited to draft statutes to compete for close corporations, and that they may have weak incentives to do so. ${ }^{10}$ While we cannot be sure about the existence of regulatory competition,

\footnotetext{
${ }^{7}$ In favor of a "race to the top,” e.g. Winter 1977; Winter 1989; Easterbrook and Fischel 1991, pp 212-27; Romano 1993. Other authors favor a "race to the bottom," at least within limits, e.g. Cary 1974; Bebchuk 1992; Bebchuk \& Ferrell 1999. Yet other scholars doubt the importance of regulatory competition, e.g. Kahan and Kamar 2002, or suggest that the interaction between federal and Delaware law had the most definite impact on the development of corporate law. Bratton 1994, pp. 418-425; Roe 2003.

${ }^{8}$ E.g. Bebchuk 1992, p 1470 n 118.

${ }^{9}$ See, e.g. Ribstein and O’Hara 2008, p 704.

${ }^{10}$ Ayres 1992, pp 392-395.
} 
there is clearly regulatory arbitrage, meaning that at least some founders actively seek out the most suitable law. Factors driving incorporation choices in closely-held business entities (both corporations and LLCs) are likely very different (even if Delaware also dominates the market for firms that are formed outside of the state of their principal place of business ${ }^{11}$ ). Courts in some US states have - at least at one time - had the tendency to apply heightened fiduciary duties in such firms, in particular to protect minority shareholders stuck with an investment for which there is no market. ${ }^{12}$ The general trend in business law has been toward more contractual freedom since the 1990s. LLCs in particular are often described as creatures of contract, ${ }^{13}$ which at least rhetorically undercuts the view that traditional common law fiduciary duties should apply. ${ }^{14}$ LLC law, for example in Delaware, today sometimes allows a complete opt out of fiduciary duties, thus leaving only a contractual duty of good faith and fair dealing. ${ }^{15}$ The policy argument here is that (minority) members of closely-held entities are typically quite well informed, and are thus in a good position to strike bargains ex ante that best serve their own interests. ${ }^{16}$ Larry Ribstein, a leading proponent of the contractarian view, thus argued that fiduciary duties should apply only where conflicts of interest between managers and outsiders resemble the situation in publicly traded corporations. ${ }^{17}$ Fiduciary duties may also become, even if initially beneficial, incrementally so burdensome that there are incentives for parties to opt out. ${ }^{18}$ However, legislation or case law protecting minority

\footnotetext{
${ }^{11}$ Dammann \& Schündeln 2011, p 85; Dammann \& Schündeln 2012, p 746 (providing descriptive statistics for closely held corporations and LLCs respectively).

${ }^{12}$ Donahue v. Rodd Electrotype Co., 328 N.E.2d 505 (Mass. 1975); Smith v. Atlantic Properties, Inc., 422 N.E.2d 798 (Mass. App. Ct. 1981); but see Nixon v. Blackwell, 625 A.2d 1366 (Del. 1993).

${ }^{13}$ E.g. Manesh 2017, p 399-406, 447-465 (surveying and criticizing Delaware case describing LLCs as creatures of contract).

${ }^{14}$ But see Frankel 1995, p 1266-67 (criticizing the erosion of fiduciary duties through empty consent).

${ }^{15}$ DLLCA § 18-1101(e).

${ }^{16}$ E.g. Romano 1992, p 412-3; Gelter 2005, p 270.

${ }^{17}$ Ribstein 2005, p 249.

${ }^{18}$ Gelter and Helleringer 2018, p 118.
} 
shareholders changes the distribution between the majority and minority shareholders. Thus, closely held firms would likely tend to incorporate in jurisdictions that favor controlling shareholders. $^{19}$

Member interests are typically closely aligned against the interests of creditors in privately held firms. Regardless of the debate whether and which creditors actually need legal protection, ${ }^{20}$ legislation intended to protect creditors seems to play hardly any role in the US regulatory competition debate. States are divided between those (like Delaware and New York ${ }^{21}$ ) that still use a legal capital system, and those - following the Model Business Corporation $\mathrm{Act}^{22}$ that do not. Legal capital rules in the US are easy to work around, and no state requires a minimum capital. ${ }^{23}$ Consequently, another creditor protection doctrine seems to matter in the market for incorporations, namely the extent to which state courts are inclined to pierce the corporate (or LLC) veil and hold shareholders liable to creditors.

Only a handful of studies have attempted to gauge the key factors driving incorporation choices of closely held firms empirically. First, some studies emphasize substantive features of the law. Dammann and Schündeln’s findings indicate that both corporations and LLCs with their principal place of business in states where veil piercing is seen to be likely are more likely to register in another state. ${ }^{24}$ They suggest that closely held corporations tend to avoid states with mechanisms

\footnotetext{
${ }^{19}$ Dammann and Schündeln 2011, p 81.

${ }^{20}$ Armour 2006, p 17-21; Adler and Kahan 2013, p 1779-81.

${ }^{21}$ DGCL $\S 170$; NY Bus Corp L § 510(b) (establishing surplus tests for the distribution of dividends).

${ }^{22}$ RMBCA $\S 6.40$ (c) (requiring a solvency test for distributions to shareholders).

${ }^{23}$ One issue that may have a similar effect as legal capital are New York's publication requirements for LLCs. See NY LLC Law $\S 206$. Costs differ by county, which may encourage founders to set up a corporation instead or choose a county where publication costs are relatively low. See Moisan 2015, p. 474. This requirement cannot be avoided by setting up an LLC in another state because analogous publication requirements apply when the LLC registers to do business in New York. NY LLC Law § 802(b).

${ }^{24}$ Dammann and Schündeln 2011, pp 95-96; Dammann and Schündeln 2012, pp 755-756.
} 
to protect minority shareholders. ${ }^{25}$ By contrast, LLCs are founded out of state to avoid a minority oppression statute. ${ }^{26}$ Overall, Dammann and Schündeln’s analysis supports the argument that substantive law creating liability risk matters, even if the direction of this effect is not entirely consistent. At least at a time, Nevada's efforts in the incorporation market were targeted at a certain segment best described as "Wild West" corporations, touting the difficulty of piercing the corporate veil, the privacy guaranteed by bearer shares, and its reticence in sharing information with the IRS. ${ }^{27}$ Since then, Nevada has also targeted the market for publicly traded corporations and provided them with the option of liability protection for directors and managers, as well as ability to defend against hostile takeovers. ${ }^{28}$

Second, the quality of the legal system overall, and the quality of the courts seems to militate in favor of Delaware. Kobayashi and Ribstein's empirical results suggest that the quality of the courts according to various indices, and the adoption of a "series LLC" provision ${ }^{29}$ - as a proxy for innovativeness - draw the registration of LLCs with their principal place of business in another state. ${ }^{30}$ This finding is consistent with the fact that LLC law in the US generally provides for a great deal of flexibility and that the parties will generally be able to tailor any state's law to their needs (as far as the relationship between the members is concerned). ${ }^{31}$ In any event, one can easily

\footnotetext{
${ }^{25}$ Dammann and Schündeln 2011, pp 95-96.

${ }^{26}$ Dammann and Schündeln 2012, pp 757.

${ }^{27}$ Kahan and Kamar 2002, p 717. On the rise of Nevada as a "liability-free” jurisdiction, see also Barzuza 2012.

${ }^{28}$ Many Nevada firms appear to be shell companies without significant activities. Anderson 2018, p 674. On the rise of Nevada as a "liability-free” jurisdiction, see also Barzuza 2012; Zorzi 2017, p 257; Eldar 2019, pp 556-560.

${ }^{29}$ A series LLC permits the creation of several "series" of assets within an LLC, which allows e.g. the compartmentalization of different types of real estate investment without the ability of creditors to go after the assets in another series. See, e.g. DLLCA § 18-218(c).

${ }^{30}$ Kobayashi and Ribstein 2011, p 128. See also Dammann and Schündeln 2011, pp $94-95$ (finding that firms from states with a court system generally to be perceived as not particularly good are more likely to incorporate outside of the state).

${ }^{31}$ Kobayashi and Ribstein 2011, pp 97, 111.
} 
argue that piercing the corporate or LLC veil can hardly be a strong factor in determining choice of state because states do not consistently apply the incorporation state's law to veil piercing. ${ }^{32}$

Third, Delaware law serves as a "lingua franca" in the law of business associations in the US. One might think that small firms have less to gain from the network effects created by the large number of Delaware corporations (and LLCs). ${ }^{33}$ However, since lawyers across the country are familiar with Delaware law, it enables them to provide investors with a set of rules that they can understand. Consistent with that, new out-of-state venture capital investors were found to be more likely to invest in firms with whose home state law they were already familiar. ${ }^{34}$ Relatedly, a study of private securities offerings found that legally more sophisticated firms were more likely to choose Delaware. ${ }^{35}$ Finally, a survey among business lawyers found that the Delaware judiciary and brand, as well as the knowledge of Delaware law mattered for the choice to set up an LLC there. $^{36}$

\subsection{Competition for privately held firms in Europe}

Before Centros, EU Member States were divided between those using the "incorporation theory" and those using the "real seat theory" in the private international law of companies. While the incorporation theory recognizes the legal existence of a business entity if it fulfills the formation requirements in the state where it was legally formed, the "real seat theory" requires that founders must follow the formation procedures of its principal place of business, i.e. the country

\footnotetext{
32 On this issue, see Dammann and Schündeln 2011, pp 89; Halabi 2015, p 1045-1046; Gelter and Vicente 2019, $\S 2.02[\mathrm{~B}][1]$.

${ }^{33}$ Ribstein and O’Hara 2008, p 703; Zorzi 2017, p 256.

${ }^{34}$ Broughman et al 2014, p 893.

35 Anderson 2018, p 694.

${ }^{36}$ Gevurtz 2012, p 105.
} 
of its "real seat.” Without following such procedures a company might face drastic consequences, up to its non-recognition or treatment as a partnership.

The purpose of the real seat theory is not to protect the creditors (or shareholders) of any particular company, but rather the protection of a country's authority to determine the law of business entities operating within its territory. Creditors might in fact be harmed if a court found that a debtor company lacked legal capacity. ${ }^{37}$ The consequences of the real seat theory compelled founders to select the law of the real seat jurisdiction, thus protecting it from competition. All of this changed with the seminal cases of Centros (1999), Überseering (2002), and Inspire Art (2003), where the Court of Justice of the European Union (CJEU), while not discussing the real seat theory as such, found its consequences to be incompatible with the freedom of establishment. In addition, Inspire Art invalidated a Dutch law that imposed certain liabilities on foreign companies with their real seat in the Netherlands.

Some of the early post-Centros literature explored whether this would transpose the US model of regulatory competition to Europe. The general tenor was that there would be considerable differences, in particular because of a lack of member state incentives to compete, and because of considerable hurdles for publicly traded firms to use regulatory arbitrage opportunities. ${ }^{38}$ However, soon after Inspire Art, the focus of the debate became privately held firms, in particular because founders of new firms increasingly seemed to set up their business as private limited companies in the UK (specifically in England and Wales). Thus, unlike in the US, privately held firms

\footnotetext{
${ }^{37}$ E.g. Hopt 2010, p 16; Gelter 2017, pp 310, 317.

38 On this debate, see, e.g. Enriques 2004; Dammann 2004; Armour 2005; Gelter 2005; Tröger 2005; Birkmose 2006; Ventoruzzo 2006.
} 
became the main focus of the debate. The nature of the aspects of substantive law apparently driving choice of jurisdiction differs between Europe and the US. While in the US the main substantive issues appear to be the ex post liability mechanisms discussed in the previous section, the European debate seemed to focus almost entirely on ex ante factors relating to the firm formation process, such as the cost and duration of setting up a limited-liability business entity, but most of all legal capital. $^{39}$

The Second Company Law Directive ${ }^{40}$ had of course largely harmonized the legal capital system for public companies (i.e. firm types such as the Aktiengesellschaft or société anonyme) for decades and set forth a minimum capital of $€ 25,000$. Private limited companies (i.e. firm types such as the $G m b H$ or $S A R L$ ) remained outside the purview of secondary EU law in this respect, which resulted in considerable variation in the amount of minimum capital and features of the legal capital regime. The UK did not require a minimum capital for private limited companies. The case law thus added further fuel to the already ongoing debate about the merits and (mainly) demerits of the legal capital system. ${ }^{41}$

To the limited extent that we have a clear picture of the market for new formations of privately held firms in the US, we can identify two differences between the US and Europe. First, free choice of corporate law has been available in the United States for much longer than in the EU. Looking at the supply side, market forces may already have asserted their cleansing effects

\footnotetext{
${ }^{39}$ Not only minimum capital, but formal steps related to capital raising, such as notarization requirements, bank confirmations and valuations of contributions in kind likely play a role.

${ }^{40}$ Second Council Directive of 13 December 1976, 1977 O.J. (L 26) 1. This directive has most recently been integrated into Directive (EU) 2017/1132 of the European Parliament and of the Council of 14 June 2017 relating to certain aspects of company law (Codification), O.J. (L 169) (Codified Company Law Directive), Chapter IV.

${ }^{41}$ E.g. Enriques and Macey 2001; Mülbert and Birke 2002; Rickford 2004; Armour 2006.
} 
and purged company law of such requirements. Arguably, if neither US states other than Delaware $^{42}$, nor European jurisdictions have incentives to attract the formation of closely held business from elsewhere ${ }^{43}$, then there appears to be no inherent reason why even costly rules with little apparent benefit should disappear. But legislatures may at times just have been motivated by the objective of facilitating business for their own constituents, of which a more streamlined corporate and LLC law would be a byproduct. ${ }^{44}$ The fact that the LLC itself was introduced and spread across jurisdictions shows that income streams from franchise fees are not a necessary condition.

Second, looking toward the demand side of the market for corporate law, we can see that the cost-benefit calculus for founders is different. European regulatory arbitrage opportunities have much lower-hanging fruit within reach. Comparatively, marginal differences in directors' duties or piercing the corporate veil likely do not impose a great cost on founders. The probability that these doctrines will become relevant is small, and litigation lies many years in the future. By contrast, up-front founding procedures and financing constraints that hinder capital formation are a much more immediate burden for founders to reckon with. ${ }^{45}$ Thus, in Europe, ex ante costs loom larger, and these will have to be incurred with certainty during the founding stage of the firm. In the US, where ex ante costs are very small in comparison, other factors may be more important.

\footnotetext{
${ }^{42}$ Kahan and Kamar 2002 (suggesting that only Delaware competes in general); but see Kobayashi and Ribstein 2011, pp 98-99 (suggesting that states have incentives to compete for LLC formations).

${ }^{43}$ Tröger 2005, pp 43-48.

${ }^{44}$ Reyes and Vermeulen 2013, pp 461-473 (suggesting that pressure from competition-oriented interest groups such as lawyers will often result in an improvement of the law of business organizations). Lawyers benefit specifically from the attractiveness of the law on which they consult, but - like other interest groups - often also from a businessfriendly environment in general.

${ }^{45}$ One might argue that minimum capital does not actually impose a cost because it is available to the firm. However, empirical evidence suggests that minimum capital requirements deter entrepreneurship because of financing constraints. Blanchflower and Oswald 1998, pp 42-46 (reporting survey results among prospective entrepreneurs); van Stel et al 2007, p 181 (showing a negative correlation between the Doing Business Report's minimum capital index and firm formations).
} 
The cost-benefit calculus is also impacted by the cost of learning about differences in the law in other jurisdictions in the first place. It is relatively low in the US, where lawyers across the country are often familiar with Delaware corporate and LLC law. In Europe, it often involves immersion in a different legal culture rooted in a different language. Informing oneself about it (even if the help of an agent) may only be worthwhile when large benefits can be made. Only differences in the law producing large gains will present themselves as viable arbitrage opportunities. Minimum capital will make the cut, but fiduciary duty and veil piercing may not. If anything, it appears that some founders during the wave of incorporations following Inspire Art underestimated the impact of aspects of English law they had not immediately considered.

This is illustrated by the early experience of German founders with the UK private limited company. One likely explanation for the decline of popularity of "Centros firms" around 2006 is that many founders underestimated the cost of maintaining a UK firm, particularly financial accounting disclosure requirements, as well as the vigor with which they were enforced by the UK authorities. As Ringe suggests, this may have resulted in the striking of a considerable number of these firms from the register. ${ }^{46}$ Compared to the relatively subtle substantive doctrinal differences in fiduciary duties and veil piercing that appear in the US debate, issues such as these should still be relatively easy to compare between countries.

Tax law might further help to explain differences in the market for initial firm formations between the US and Europe. While in the US corporate tax is largely federal and states generally only tax in-state profits, EU member states generally apply the real seat principle to corporate

\footnotetext{
${ }^{46}$ Ringe 2013, pp 261-263.
} 
taxation. ${ }^{47}$ At least in theory, this means that incorporation in another Member State should not affect taxation for a newly founded firm because the real seat state retains the authority to tax. ${ }^{48}$ At the initial firm formation stage, European firms after Centros can combine the desired corporate law with the desired tax law in situations where profit can be transferred to a holding company or subsidiary with its real seat in a low-tax jurisdiction. ${ }^{49}$ With corporate law likely being of small relevance for wholly-owned firms within a group, regulatory competition studies might pick up incorporations of this type in their data collection efforts.

\subsection{Insolvencification and defensive regulatory competition}

As we have seen, competition in the market for newly founded firms in Europe affects mainly firms' relationships with creditors. Member States professing their intention to protect creditors reacted with two legislative strategies, which have been described as "insolvencification” and "defensive regulatory competition." 50 Both concern mainly the Member State's attempts to preserve certain creditor protection mechanisms for companies operating in its territory. In both cases, the country in question attempts to retain control of the law applying to corporations operating mainly within its territory, but with very different effects.

Insolvencification constitutes the legislative, jurisprudential or doctrinal recharacterization of a corporate law mechanism as insolvency law. ${ }^{51}$ Under the European Insolvency Regulation, the applicable insolvency law is determined not by a corporation's registered office, but by the

\footnotetext{
${ }^{47}$ Kane and Rock 2008, pp 1265, 1271.

${ }^{48}$ E.g. Dammann 2005, pp 71-72; Tröger 2005, pp 16-18.

${ }^{49}$ Kane and Rock 2008, p 1272.

${ }^{50}$ Enriques and Gelter 2007, pp 588-591, 640-644; see also Gelter and Vicente 2019, §2.02[A][2].

${ }^{51}$ See, e.g. Lennarts 2017, pp 127-128.
} 
debtor company's Center of Main Interest (COMI) ${ }^{52}$ If a creditor protection doctrine is credibly qualified as insolvency law, then it would apply to a corporation regardless of which corporate law applies to it. A prominent example is a German 2008 reform titled Gesetz zur Modernisierung des GmbH-Rechts und zur Bekämpfung von Missbräuchen (MoMiG). ${ }^{53}$ Among other things, the law arguably "insolvencified" directors' liability for failing to file for insolvency, as well as the subordination of shareholder loans, by placing these doctrines in insolvency law, but also modifying some of their features. ${ }^{54}$ The CJEU went a step further in its 2016 Kornhaas opinion, in which it effectively "insolvencified” the German directors' liability statute as it existed before MoMiG. Applying a functional test, the court characterized it as insolvency law, even if at the time its legal basis was in corporate law (specifically $\S 64 \mathrm{GmbHG).}{ }^{55}$

While insolvencification attempts to retain the existing law, defensive regulatory competition actually results in a modification of the law. ${ }^{56}$ When applying this technique, Member States seek to remove or reduce particularly unattractive features of their corporate law to quell the "flow" of newly founded firms to more attractive jurisdictions. ${ }^{57}$

Three types of reforms can be characterized as defensive regulatory competition. First, Member States have tried to streamline the firm formation process. For example, as early as 2003,

\footnotetext{
${ }^{52}$ Art. 3 of Regulation (EU) 2015/848 Of The European Parliament and of the Council of 20 May 2015 on Insolvency Proceedings (recast), 2015 OJ (L 141) 19.

${ }^{53}$ Gesetz zur Modernisierung des GmbH-Rechts und zur Bekämpfung von Missbräuchen (MoMiG) ["Law for the Modernization of the German Limited Liability Company Law and the Prevention of Misuse.”], 23.10.2008, BGBl I, p 2026.

54 §§ 15a, 39 InsO (Germany); see, e.g. Lennarts 2017, pp 114-115, 117-118.

${ }^{55}$ Simona Kornhaas v. Thomas Dithmar, Case C-594/14. But see Ringe 2017, p 273 (criticizing the court's reasoning as unpersuasive).

${ }^{56}$ For the use of the term, e.g. Enriques and Gelter 2007, p 424; Enriques and Gelter 2007, p 600; Ringe 2013, p 243.

${ }^{57}$ While outside of the purview of this article, the introduction of loyalty shares to discourage the transfer of publicly traded firms (seeking security from hostile takeover) to another Member State may also be characterized as defensive regulatory competition. See Pacces 2016, p 213.
} 
Spain created a new company type called Sociedad Limitada Nueva Empresa (SLNE), which was subject to certain limitations, but could be formed within 24 hours. ${ }^{58}$ Other member states have made progress in this area as well. Even Austria allows a simplified firm formation procedure for single-member GmbHs from 2018 onwards. ${ }^{59}$ With the enactment of the Commission’s proposal on digital tools in company law ${ }^{60}$ as a directive, differences between Member States will likely further decrease in favor of faster firm formation procedures.

Second, a number of member states have introduced special private company forms with smaller or no legal capital requirements. Here, we see quite a bit of variety. Germany’s MoMiG provides one of the most well-known examples by creating a modified form of the GmbH called Unternehmergesellschaft (haftungsbeschränkt), which does not require a minimum capital, but which must retain all of its profits until the regular minimum capital is reached ${ }^{61}$ Another example is Belgium, which introduced the societé privée à responsabilité-starter, or SPRL-S in $2010 .{ }^{62}$ The SPRL-S was subject to certain limitations, but was not subject to the ordinary minimum capital of $€ 18,500$. The law initially provided that "starter" firms had to increase their capital to the minimum amount within five years from registration. ${ }^{63}$ A 2014 reform removed this restriction, as well as a limitation to no more than 5 full-time employees. ${ }^{64}$

\footnotetext{
${ }^{58}$ Ley 7/2003, de 1 de abril, de la sociedad limitada Nueva Empresa por la que se modifica la Ley 2/1995, de 23 de marzo, de Sociedades de Responsabilidad Limitada, BOE. 2003, no 79. See Braun et al 2013, p 405.

59 § 9a GmbHG (Austria).

${ }^{60}$ Proposal for a Directive of the European Parliament and of the Council amending Directive (EU) 2017/1132 as regards the use of digital tools and processes in company law, April 25, 2018, COM(2018) 239 final.

$61 \S 5$ a GmbHG (Germany).

${ }^{62}$ Loi modifiant le Code des sociétés et prévoyant des modalités de la société privée à responsabilité limitée «Starter», Moniteur Belge, January 26, 2010, p 3158. The law came into force June 1, 2010. See Arrêté royal, May 27, 2010, Moniteur Belge, May 31, 2010, p. 32586, art 4.

63 Former Code des sociétés, art 214. For details, see Bartolacelli 2017, p 206-210.

${ }^{64}$ Loi portant dispositions diverses en matière de P.M.E, January 15, 2014, Moniteur Belge, February 3, 2014 , p 9106.

Other countries have followed suit, including some of the new Member States. For example, Croatia also created a
} 
Third, a number of Member States have considerably reduced or even eliminated minimum capital requirements for private limited companies. For example, a Dutch reform of 2012 reduced the minimum capital of the Besloten vennootschap to one cent. ${ }^{65}$ Belgium's 2019 company law adopted an even more radical solution when it abandoned the legal capital system for the SARL/BV entirely. ${ }^{66}$ Similar trends have prevailed in the formerly communist Member States that have or had a minimum capital. For example, the Czech Republic reduced its minimum capital to 1 Kč with the 2012 Companies Act. ${ }^{67}$

Beyond these examples, we can identify a general trend toward the simplification of company formation procedures and a reduction, even elimination of capital requirements. Legislators' true (and likely diverse) motives for any particular reform are hard to gauge. In fact, in many cases the objective may not have been exclusively or partly of a defensive nature, but rather to improve the entrepreneurial environment more generally, without necessarily having regard to a flight of new firm formations to the UK, or to improve the country’s ranking in the World Bank's "Doing Business” Report. ${ }^{68}$

But as far as the "defensive" motive is concerned, one could say states could be legitimately interested in retaining control over the legal framework of business associations operating mainly within their territory. Other than in the US, whose constituent states share the same legal culture, in Europe there may be a considerable cost for parties interacting with firms governed by the laws

\footnotetext{
simplified private company form in 2012, which required only a nominal minimum capital. Zakon O Izmjenama I Dopunama Zakona O Trgovačkim Društvima, NN 111/2012.

${ }^{65}$ Art. 2:178 Civil Code (Netherlands). See Bartolacelli 2017, p. 194.

${ }^{66}$ Code des sociétés et des associations of March 23, 2019, Moniteur Belge of April 4, 2019, p 33239, art.5:1 (defining the SARL as a capital-free company form whose members are liable only with their contributions).

${ }^{67} \S 142$ Zákon ze dne 25. ledna 2012 o obchodních společnostech a družstvech (Czech Republic). The reform came into force in 2014.

${ }^{68}$ For Italy, see Bartolacelli 2016, p. 705.
} 
of other Member States. Members, creditors and other constituencies interacting with a firm may have to incur considerable information efforts to deal with an entity governed by unfamiliar law. ${ }^{69}$ Some of these may be able to adjust to these circumstances, but others may not, or may underestimate risks.

Leaving such an idealized vision of legislative motives aside, a more realistic explanation has to be rooted in an analysis of interest group shaping such ideals and consequently legislative developments. From a regulatory competition perspective, one would argue that if creditors actually benefit from capital requirements, they would push for their retention and thus against defensive regulatory competition measures. However, they could also recognize that an evasion of domestic corporate law by pseudo-foreign incorporations would be more harmful to them, and that they would benefit more if the overwhelming majority of firms were set up under domestic law, albeit with relaxed requirements. Given that the actual value of the prevailing creditor protection rules is today very much in doubt, however, one is tempted to suspect that the domestic legal profession may be the main interest group that might want a Member State to retain control over corporate laws within its territory. Lawyers and notaries (who often earn fees for registering companies or their branch offices ${ }^{70}$ ) might be concerned about losing business of founders were to incorporate in another Member State. In a similar vein, Halbhuber provocatively suggested that German legal scholarship rejected the incorporation theory - in spite of the freedom of establishment - because it served the interests of the domestic legal establishment. Business lawyers and

\footnotetext{
${ }^{69}$ E.g. Gelter 2005, p. 268.

${ }^{70}$ See, e.g. Becht et al 2009 (providing figures for the fees earned by notaries for registering branch offices in a number of jurisdictions).
} 
legal academics may have been concerned about losing consulting opportunities to foreign colleagues. ${ }^{71}$

\section{Tackling the empirical effects of defensive regulatory competition}

\subsection{Centros as the object of empirical research}

During the remainder of the paper, I present partial results from a larger ongoing research project, in which I am attempting to explore the effects of defensive regulatory competition. ${ }^{72}$ Since Centros, $a$ number of studies have attempted to analyze the number of cross-border firm formations empirically. In an early paper, John Armour used a set of German search terms indicative of a likely real seat in Germany to locate such firms in the English Companies House database at the time and already observed an increase in 2003 and 2004. ${ }^{73}$ Subsequent papers used Bureau van Dijk's various databases to identify and count Centros-style firms. ${ }^{74}$ Each of these studies looked at either the residency or citizenship of directors and classifies a firm, for example, as German if either at least one, the majority, or all of its director and managers are German. ${ }^{75}$ The papers differ in their exact research objective. While Becht et al (2008) set up a panel to explore the impact of the Centros case, Gerner-Beuerle et al (2018) use only cross-sectional data to determine whether the number of cross-country incorporation is influenced by conflict of law rules. Ringe (2013) compares the number of Austrian and German Centros-style firm formations over

\footnotetext{
${ }^{71}$ Halbhuber 2001, pp 1413-1414.

${ }^{72}$ Gelter (work in progress).

${ }^{73}$ Armour 2005, pp 385-386.

${ }^{74}$ Becht et al 2008; Braun et al 2013; Ringe 2013, pp 247-253; Gerner-Beuerle et al 2018.

75 Becht et al 2008, and Braun et al 2013, p 407, look at whether either the majority or all directors are residents of a particular country. Braun et al also use data from the German and Polish company registers. Ringe 2013, p 247, and Gerner-Beuerle et al 2018, p 17, look at whether at least one director is a citizen of the country in question. Some of the papers apply additional constraints. Ringe looks only at firms that likely use an agent (indicated by sharing an address with 100 other firms). Gerner-Beuerle et al include only firms where the majority of managers are also shareholders.
} 
time, whereas Braun et al (2013) use difference-in-difference regressions to explore the impact of legal reforms on the affected type of firm relative to other firms in the same country.

\subsection{Constructing time series to capture the Centros phenomenon}

For the research underlying a companion article ${ }^{76}$, I replicate the search strategy used by the existing literature with some modifications, following most closely Gerner-Beuerle et al (2018), but setting up a panel counting firms found by year from 1990 to 2016. In two separate searches conducted on November 28, 2017, I downloaded all firms coded in the ORBIS database ${ }^{77}$ as located in the UK and having a least one director either a citizen or resident of an EU or EFTA country. ${ }^{78}$ The searches only included firms coded as the standardized "private limited company" form and founded between 1990 and 2016. Using the residence data, this yields a list of 197,582 firms using the residence of directors as the criterion, and 1,007,407 firms using citizenship data. Unlike some of the other authors, I did not use Orbis’ somewhat limited aggregation functions to count the number of firms formed in each time period, but wrote my own $\mathrm{R}$ code to calculate a citizenship/residency coefficient for each country and firm, giving equal weight to each director and counting citizenship proportionately. Orbis also lists many managers with multiple citizenships. E.g. a director with citizenships in countries A and B would count as .5 persons for country A and .5 persons for country B. ${ }^{79}$

\footnotetext{
${ }^{76}$ Gelter (work in progress).

77 https://orbis.bvdinfo.com.

78 The Freedom of Establishment also applies to Switzerland. See Agreement between the European Community and its Member States, of the one part, and the Swiss Confederation, of the other, on the free movement of persons, 2002 O.J. (L 114) 6, annex I, art 18 (extending the freedom to provide services to companies).

${ }^{79}$ The computations necessary to convert the somewhat cumbersome export from Orbis into timelines for each country were carried out in R.
} 
What firms should count as "pseudo-foreign" incorporation is of course quite arbitrary and involves a number of choices. It is, for example, not obvious how to deal with directors/managers without citizenship or residency information. I created timelines for each country using different criteria. In analysis underlying the subsequent figures, I developed three timelines for each country. Panel A counts UK-incorporated firms where all directors are citizens of a particular country ${ }^{80}$; Panel B counts UK-incorporated firms where the majority of directors are residents of the respective country; ${ }^{81}$ and Panel C counts UK-incorporated firms where the majority of directors are citizens of the respective country and the firm used an agent (ignoring directors with unknown citizenship information) ${ }^{82}$ I followed Ringe (2013) in identifying firms using an agent based on their sharing an identical registered office address with 100 other firms in the UK. ${ }^{83}$

The graphs shown in Figure 1 aggregate all firms founded by year in each panel across all countries. We see growth after the early 2000s everywhere, which was likely triggered by the case of the European Court of Justice. ${ }^{84}$ Panel C only catches up with the other panels at approximately that time, and then moves in unison with Panel A for a few years. Panel A shows strong growth after 2009, whereas the other panels remain stable. The divergence supports the possibility that immigrants to the UK founded many firms in recent years, and lends itself to the conclusion that it is likely best to work with Panel C for further analysis.

\footnotetext{
${ }^{80}$ In this panel, a single directors/manager with unknown citizenship or an (additional) citizenship from another country already means that the firm is not counted.

${ }^{81}$ This means that the resident coefficient, ignoring directors with unknown residency information, is larger than .5.

${ }^{82}$ On the question whether citizenship or residence data are preferable, see below notes 85-88 and accompanying text.

${ }^{83}$ The office addresses have to match precisely. In spite of this exacting criterion, there were 559 such addresses accounting for a total of 248,023 out of 1,007,407 firms.

${ }^{84}$ This is shown by Becht et al 2008.
} 


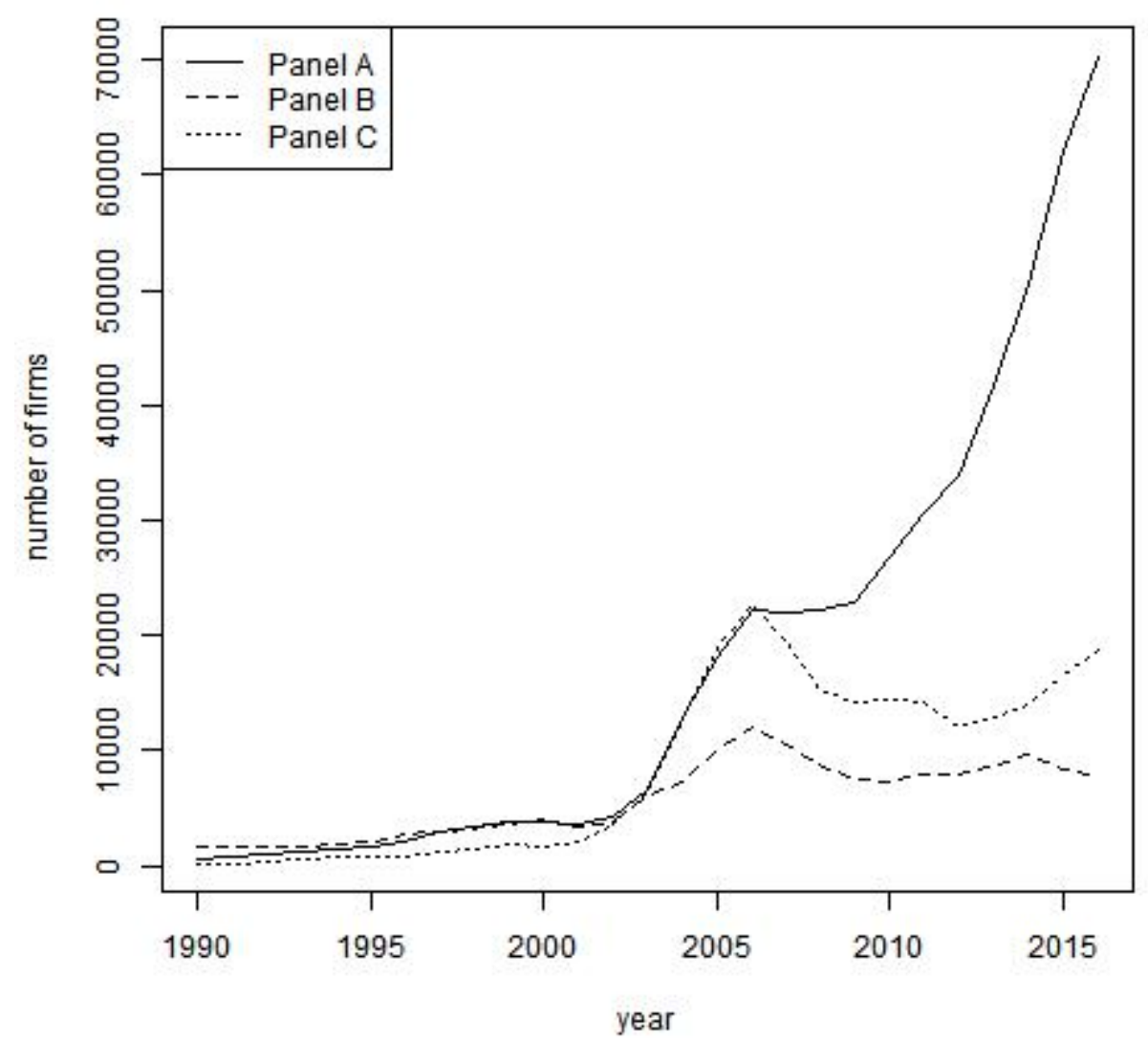

Figure 1: Overall trends for pseudo-foreign incorporations in the UK

Figure 2 shows the development of the three panels for nine selected countries between 1995 and 2012. Some countries, such as France, Italy, and Spain, exhibit a continuous upward trend in Panel A during the past few years. Some do not, e.g. Germany, the Netherlands or Austria, which indicates that the larger presence of newer firms in this model is not due to an unexplained attrition of older firms in the database. For many jurisdictions, the three panels move largely in parallel, indicating they capture the same phenomenon. For example, Austria and Germany's incorporations spike in the mid-2000s. Belgium and the Netherlands spike only a few years later. In some countries, such as Italy and Spain, the possibility of forming a private limited company was 
seemingly discovered only with considerable delay. A possible explanation is that practical hurdles that made cross-country incorporations difficult ${ }^{85}$ have eroded.

${ }^{85}$ See Becht et al 2009. 

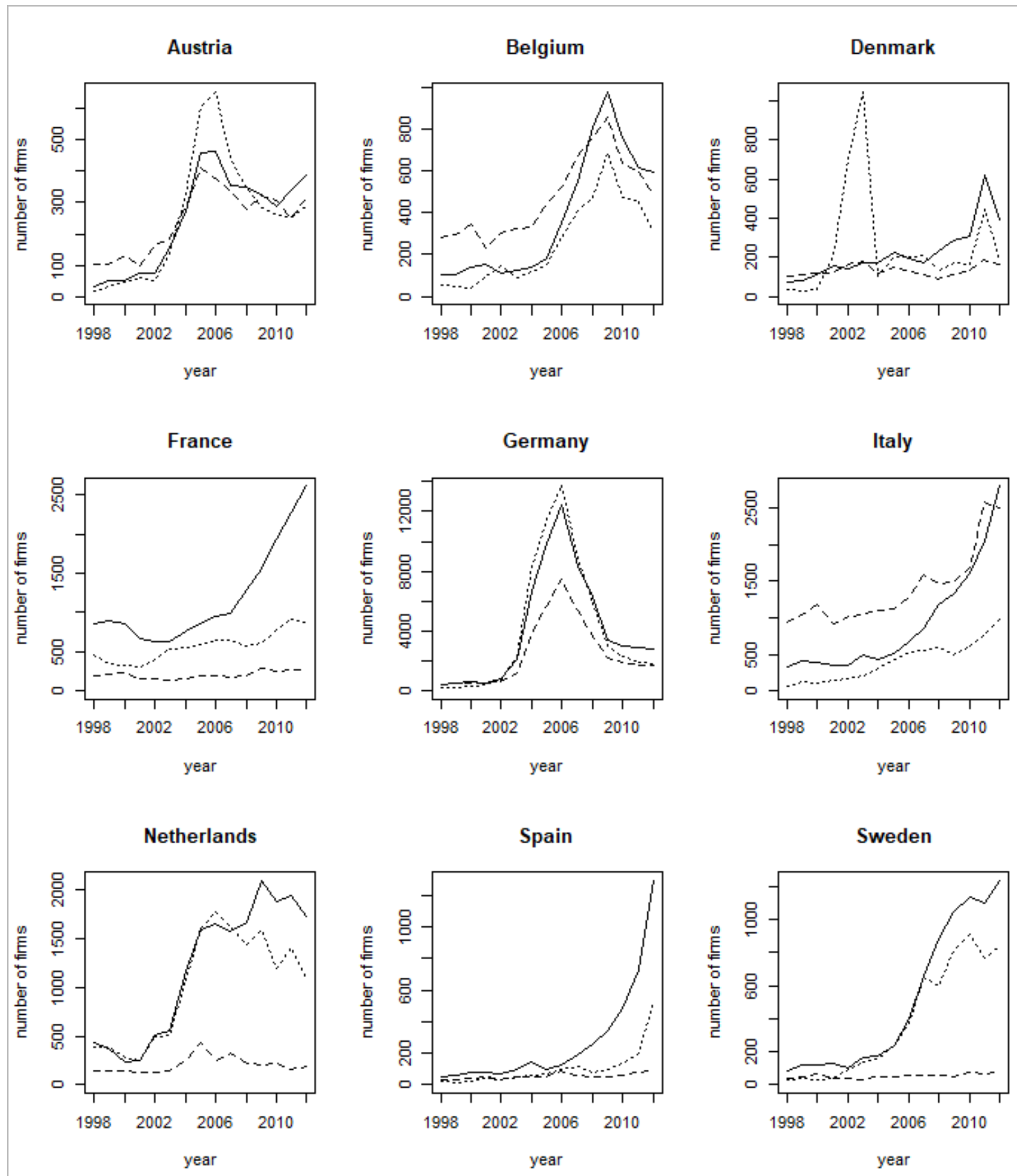

Figure 2: Overall trends for pseudo-foreign incorporations in the UK

Solid line (A): Firms where all directors are citizens of the country

Dashed line (B): Firms where the majority of directors are residents of the country

Dotted line (C): Majority of directors are citizens and firm uses an agent 
It is not entirely clear how to quantify the Centros phenomenon based on this information. In theory, the director's and managers' place of residence seems preferable as the criterion, given that one would expect a privately held firm to incorporate in the jurisdiction where the key individuals are located. This is the approach taken by Becht et al (2008), whose data end in 2006. However, under Chapter 8, Part 10 of the Companies Act 2006, the publication of a directors' residential address is now optional, which is why residence data lead to undercounting.

Citizenship data are more comprehensive, but are vulnerable to trends in international migration. If the number of citizens of a country living in the UK has increased, we can expect more of these individuals to found private limited companies in the UK; measuring the number of these firms then necessarily overestimates the Centros phenomenon. Estimates about the number of migrants can be obtained from the United Nations, which provide estimates every 5 years. ${ }^{86}$ Figure 3 shows the ratio of the estimated number of citizens of EU and EFTA countries on a logarithmic scale. If the numbers for 1995 and 2015 are the same, the country would be on the diagonal line. There is only one country below the line, namely Ireland, where the number of migrants has presumably decreased. All other countries are above the line, but to a different extent. Countries where the number of migrants increased strongly, such as Poland, Bulgaria, Romania, Slovakia and the Baltic states are far above the line.

\footnotetext{
${ }^{86}$ www.un.org/en/development/desa/population/migration/data/estimates2/estimates15.shtml. See also Gerner-Beuerle et al 2018, p 23.
} 


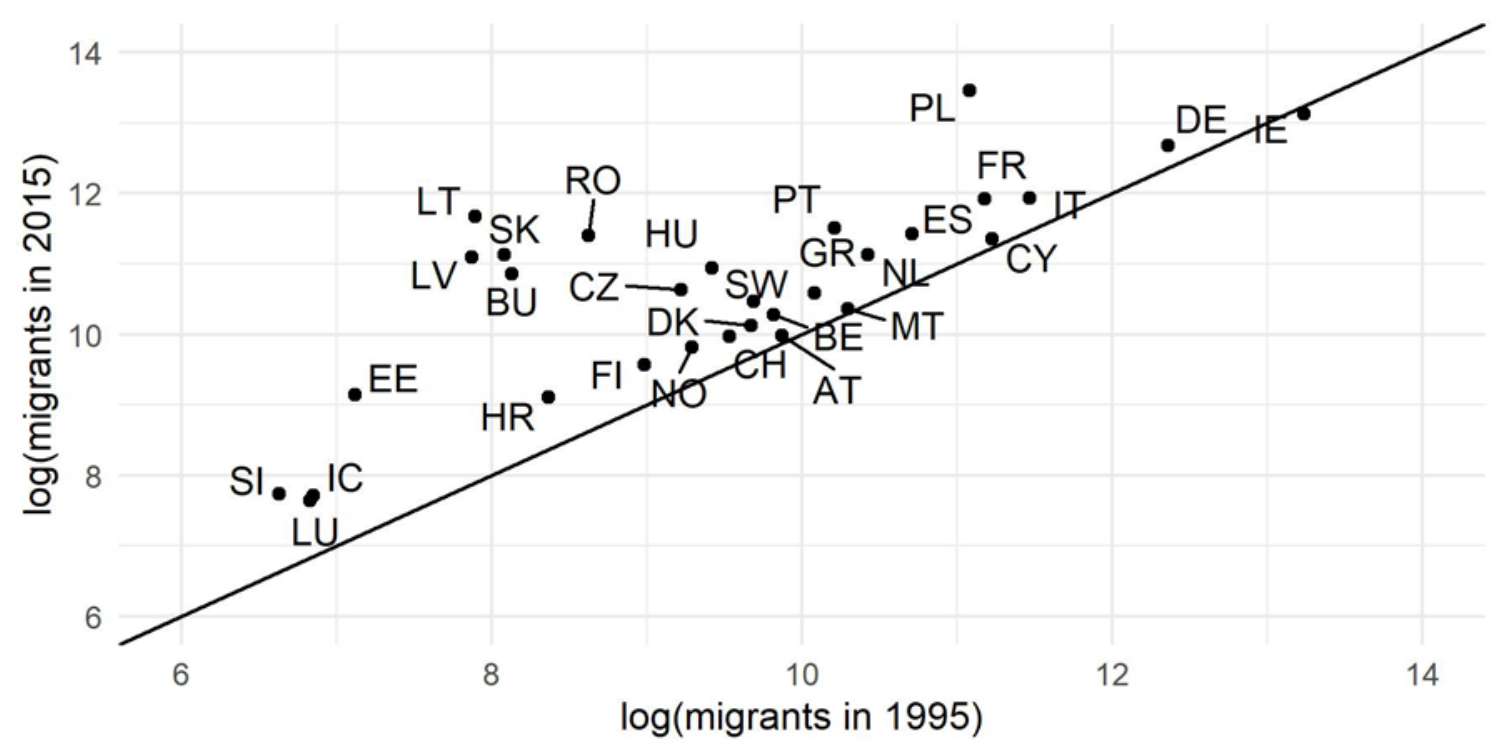

Figure 3: Relationship between number of migrants in 1995 and 2015

Differential migration rates make it hard to compare Centros-style firm formations between different countries, especially in the newer Member States. While one possibility is to adjust the raw data for the estimated number of firms formed by migrants from a given country, ${ }^{87}$ the better way to capture only the Centros phenomenon is probably to include only firms using an incorporation agent with a shared registered office ${ }^{88}$, which individuals already living in the target country will likely not need to do.

\subsection{Is defensive regulatory competition even necessary?}

The empirical investigation allows us to assess whether defensive regulatory competition is necessary and legitimate from a policy perspective. If cross-border firm formations remain a fringe phenomenon even after Inspire Art, then it seems hard to make the argument that it is needed for the respective jurisdiction to retain control over the law primarily operating within its territory

\footnotetext{
${ }^{87}$ Gerner-Beuerle et al 2018, p 18.

${ }^{88}$ Ringe 2013, pp 247-253. Ringe uses the FAME database, which is restricted to UK data but is otherwise equivalent.
} 
(even if policymakers likely had a different impression in the early years). Figure 4 shows the estimated ratio of "Centros” firms to overall firm formations (Panel C) for selected countries.

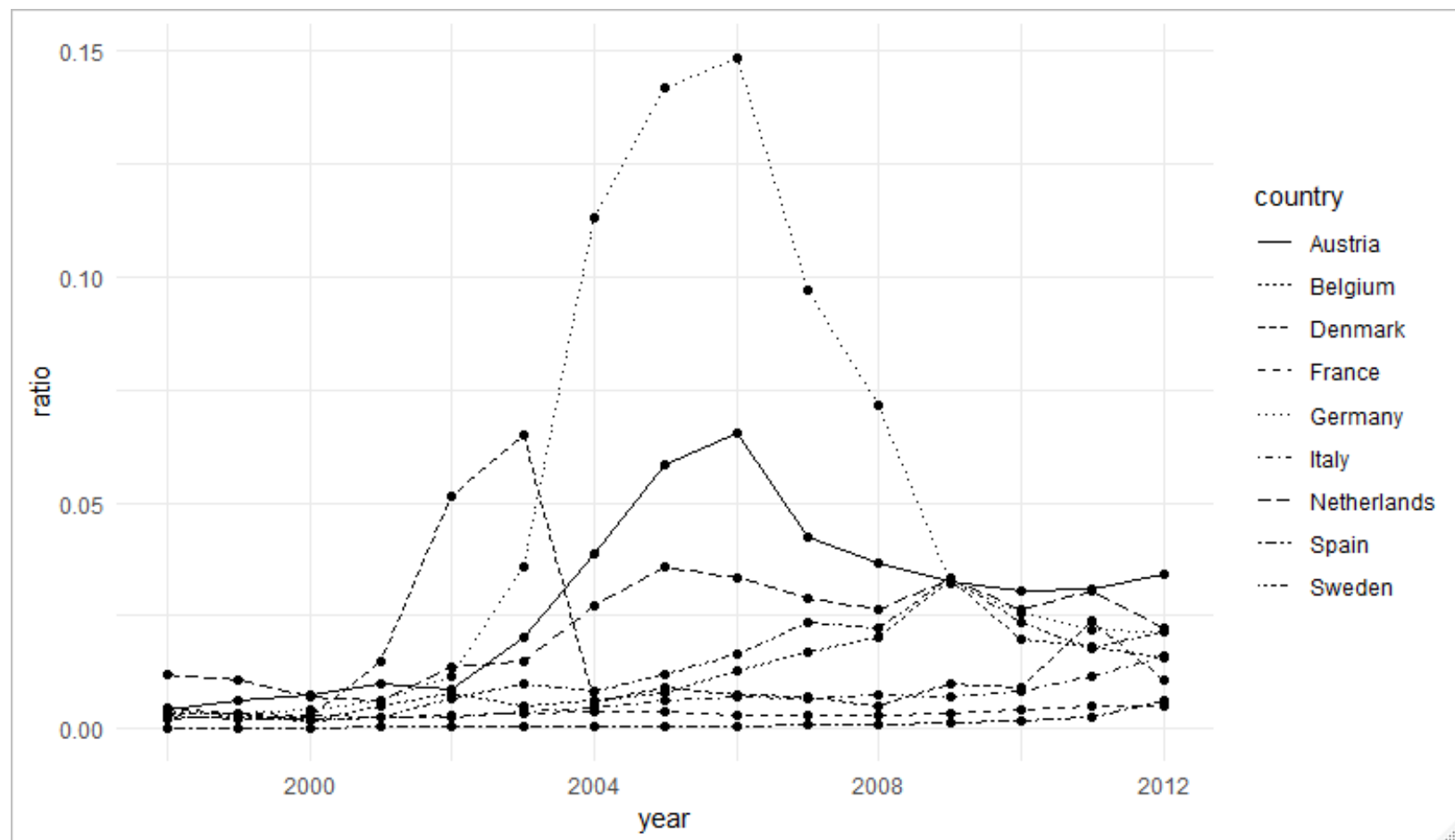

Figure 4: Ratio of UK-registered private limited companies to private and public limited company formations in the host country

Only in Germany did the ratio reach almost $15 \%$ in two years. Otherwise, only Denmark and Austria showed a share of more than $5 \%$ in a single year each. The overall conclusion might be that the impact of Centros and its follow-up cases on the national market of incorporation was only minor.

It is even more revealing to look at the number of German firms founded in those years that were still active at the time of the search (in fact, many will likely never have developed significant activity). The number of German firms in Panel C (the "agent” category) is shown in Figure 5. 


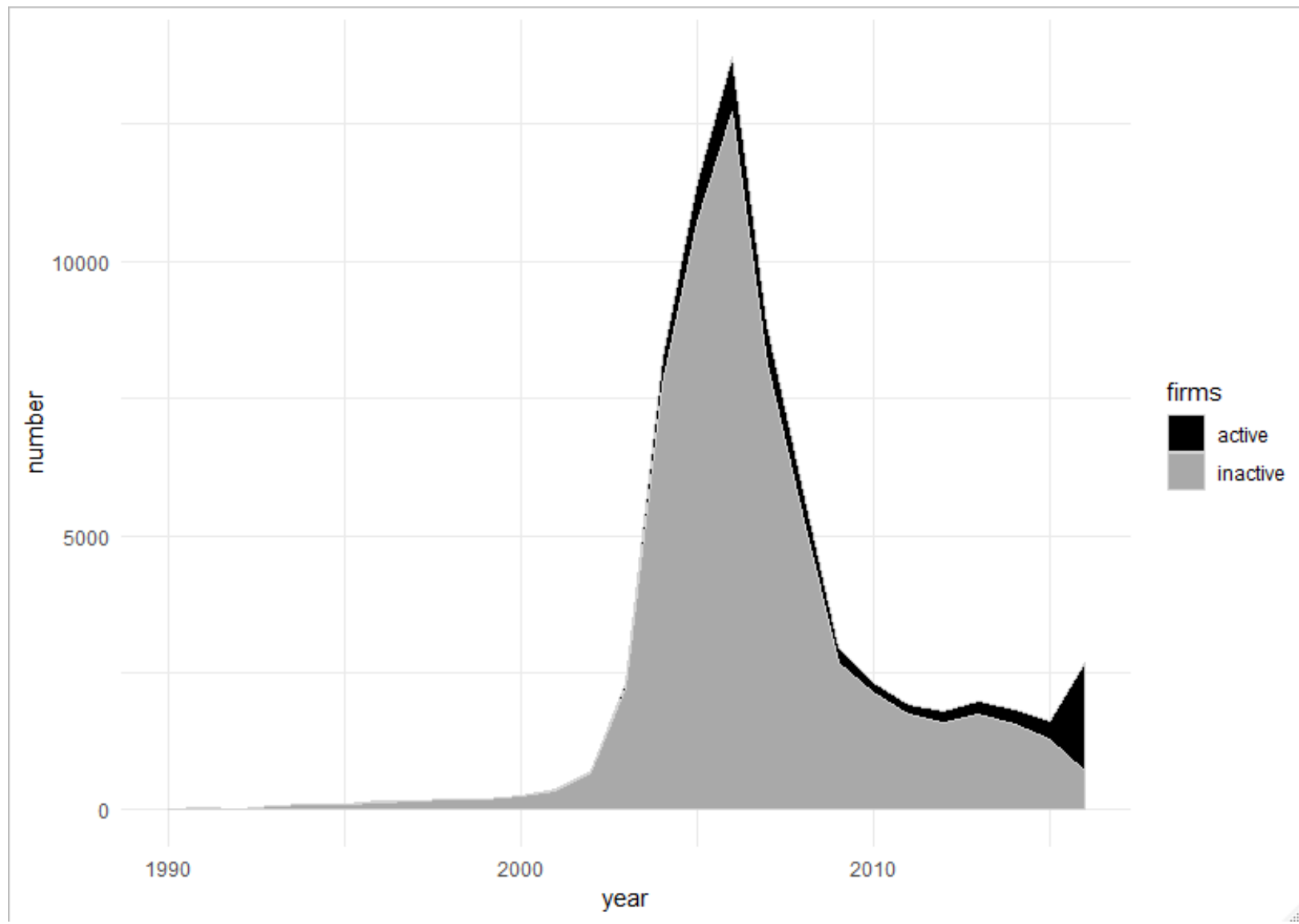

Figure 5: Number of German firms formed in the UK by activity status

Clearly, with the exception of firms founded relatively recently, the vast majority of firms showing up in the database at the time of the search were listed as inactive. Quantitatively, it thus appears that Centros incorporations have remained a fleeting phenomenon.

\subsection{Exploring the impact of defensive regulatory competition}

\subsubsection{Germany v. Austria}

One way of investigating the impact of defensive regulatory competition is to compare the timelines between two different jurisdictions that are otherwise relatively similar. Braun et al use this approach implementing a difference-in-difference regression when they compare the formation of firm types affected by a reform with unaffected ones. For example, in Spain, Germany, 
and France, they compare private limited companies (which were affected by reforms) with public limited companies (which were not). ${ }^{89}$

A related approach is to compare firm formations between countries exhibiting similar patterns in firm formations. Germany and Austria constitute one such pair; these two countries share a language and similar legal cultures as well as corporate laws, and their economies are closely integrated. Maybe most importantly, the reactions to the possibility of a UK-based pseudo-foreign incorporation in the legal and business communities were largely the same. Both countries also have not seen a significant change in the number of their citizens living in the UK. After the ECJ opened up the possibility of incorporating in the UK, policymakers and the respective legal professions were concerned that founders could now circumvent important creditor protection mechanisms of national law.

Both Germany and Austria exhibited a spike in 2006 and a subsequent reduction of the number of pseudo-foreign incorporations in the UK. As noted in section 2.3, Germany passed the MoMiG reform in 2008. Austria reacted more slowly - in spite of an equally intense debate in the legal literature - and initially retained the minimum capital of $€ 35,000$ (half of which must be paid in prior to registration). After some rather erratic legislative developments, since March 2014 Austrian GmbHs are considered "privileged” (gründungsprivilegiert) during the first ten years after formation. For this period, the firm's statutes must specify a "privileged" capital of at least $€ 10,000$, of which at least $€ 5,000$ must be contributed in cash prior to registration. ${ }^{90}$ Ringe pointed out that the number of "German" and "Austrian" limited company incorporations in the

\footnotetext{
${ }^{89}$ Braun et al 2013, p 409.

$90 \S \S 6,6 a, 10,10 b$ GmbHG (Austria). See, e.g. Bartolacelli 2017, pp 212-215.
} 
UK went down after 2006 concurrently in spite of the difference in the domestic legislation. He suggests that the reduction is more likely explained by actions in the UK that affected both countries equally. In particular, founders may not have been aware of hidden costs of incorporation, and the reduction of firm formations seems to coincide with the likely time when it became apparent that the Companies House would strike firms from the register if they did not show signs of activity, in particular by repeatedly failing to submit their balance sheet. ${ }^{91}$

Germany has about 10 times the population and about 9 times the GDP of Austria. Before 2002, German firms are slightly underrepresented, with slightly more than 6 times as many German than Austrian firms. Subsequently, German firms are overrepresented, with about 25 times as many German than Austrian firms in 2004, and 21 times the number in 2006, when the numbers peak in both countries. The ratio between German and Austrian firms then declines to 17 in 2008, 10.5 in 2009 and slightly less than 9 in 2010. Nevertheless, the comparison between the two countries can serve as a useful test case because the two countries' corporate laws and legal systems are very similar. While the MoMiG law is not a natural experiment, the concern about Centrosstyle firm formations was considerable in both countries at the time. While there were more German firms than Austrian firms relative to the size of each country, the reason why Germany introduced a reform rather than Austria was the latter's tendency to follow developments in Germany with some delay. ${ }^{92}$

\footnotetext{
${ }^{91}$ Ringe 2013, pp. 262-263.

${ }^{92}$ The Austrian Aktiengesetz has its origins in German law, which is one of the reasons why policymakers and scholars follow developments in Germany closely. See, e.g. Spamann 2009, p 1825 n. 27. Kalss 2015, p 159. But note that, unlike most other business law, the Law on Private Limited Liability Companies (GmbHG) of 1907 was not replaced by a German equivalent in 1938.
} 
We can also attempt to tackle the issue with statistical analysis and perform a Difference in-Difference (DiD) regression looking only at these two time series. Unlike in the previous figures, Figure 6 shows timelines for the two countries from 2000 to 2016 broken down on a monthly basis. This has the advantage of yielding a much larger number of observations and the possibility of tweaking the "treatment date" of the legal reform in question more accurately. The disadvantage is that control variables one could use on a yearly basis are not available or cannot easily broken down to the monthly level. While the first panel of Figure 6 shows the timelines in terms of the number of firm formations, in the second panel they are transformed to a logarithmic scale. 


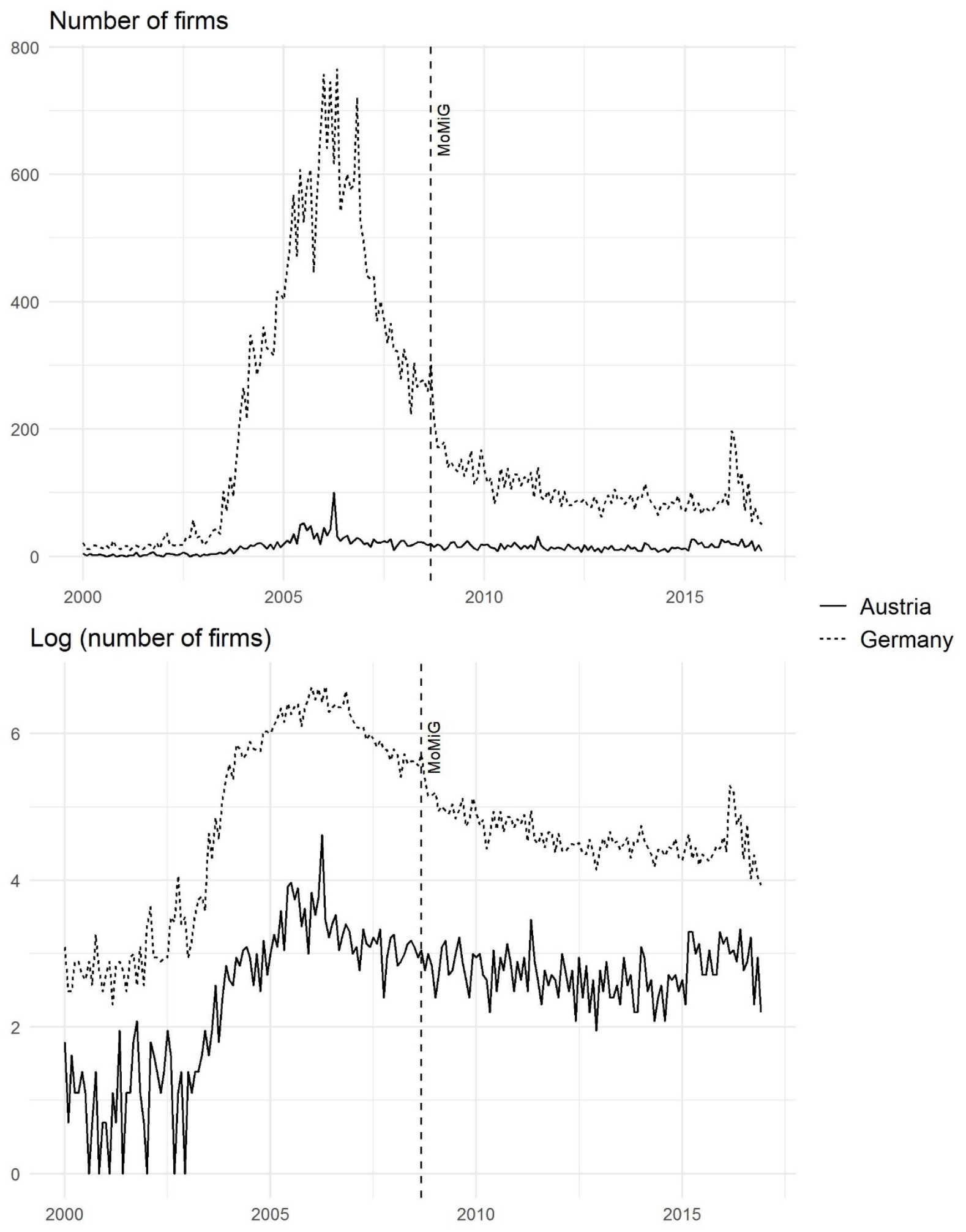

Figure 6: Monthly firm formations ( $>.5$ directors/managers are citizens, incorporation agent) for Austria and Germany 
The upper panel shows the usual peak in 2006 and a decelerating downward trend in Germany in the following years. At the time of the coming into force of MoMiG (November 1, 2008), there is a further reduction in Germany that is not paralleled in Austria. Figure 6 uses only one particular definition of "Centros firms", but the same phenomena can be seen when a different definition is used. ${ }^{93}$

The logarithmic scale does not show the same development as clearly, but it has the advantage that the two countries exhibit a parallel trend, which allows a difference-in-difference regression to test the impact of the reform. ${ }^{94}$ To test the null hypothesis that the law had no effect, we can employ the following regression model:

$$
\begin{gathered}
\log \left(y_{i j}\right)=\alpha_{j} \cdot \text { month }_{j}+\beta \cdot \text { industry_output }_{i j}+\gamma_{1} \cdot \text { Germany }+\gamma_{2} \cdot \text { post_MoMiG }_{-} \\
+\delta_{1}(\text { Germany } \times \text { post_MoMiG })+\delta_{2}(\text { Germany } \times \text { time })+\varepsilon_{i j}
\end{gathered}
$$

The results are shown in Table 1. The dependent variable is the logarithm of the number of companies founded in each month from January 2000 to December 2016. $\alpha_{j}$ represents year fixed effects. industry_output is taken from Eurostat and represents industrial production in the country in a given month. The variable is intended to control for the business cycle. ${ }^{95}$

The subsequent terms set up the DiD model, with indicator variables for Germany, the months after November 2008, and the interaction term between Germany and post_MoMiG. Thus, the regression looks at the impact of MoMiG and takes Austrian firm formations as the control

\footnotetext{
${ }^{93}$ I drew the same plots for timelines showing firms where all directors are German/Austrian citizens, where the majority are, and where a single director is, both with and without limiting included firms to those using an agent for company registration.

${ }^{94}$ In addition, the logarithmic transformation allows the use of simple OLS regression, which assumes normally distributed residuals.

${ }^{95}$ Braun et al 2013, p 409.
} 
group for Germany. In the first two regressions, the dependent variable is the number of firms where all directors/managers are citizens of Germany or Austria, and in the second two the majority of the directors/managers are citizens, and the firm uses an agent. The second and fourth regressions include a country-specific time trend $\delta_{2}$, which is recommended in the literature to test the parallel trend assumption. ${ }^{96}$ Table 1 reports panel Newey-West standard errors accounting for heteroscedasticity and autocorrelation. ${ }^{97}$

Table 1: Monthly regressions for Austria/Germany

\begin{tabular}{lllll}
\hline & All citizens & & \multicolumn{2}{c}{$\begin{array}{l}\text { More than half are citizens \& } \\
\text { incorporation agent }\end{array}$} \\
\hline Industry output & $-0.042^{* * *}$ & $-0.039^{* * *}$ & $-0.048^{* * *}$ & $-0.040^{* * *}$ \\
& $(0.007)$ & $(0.007)$ & $(0.008)$ & $(0.007)$ \\
Germany & $2.992^{* * *}$ & $2.838^{* * *}$ & $2.786^{* * *}$ & $2.379^{* * *}$ \\
& $(0.067)$ & $(0.282)$ & $(0.070)$ & $(0.265)$ \\
Germany* & $-0.966^{* * *}$ & $-1.025^{* * *}$ & $-0.912^{* * *}$ & $-1.067^{* * *}$ \\
post_MoMiG & $(0.077)$ & $(0.136)$ & $(0.075)$ & $(0.121)$ \\
Germany*time & & -0.001 & & -0.002 \\
& & $(0.001)$ & & $(0.001)$ \\
Month fixed ef- & Yes & Yes & Yes & Yes \\
fects & & 0.964 & 0.950 & 0.950 \\
\hline $\mathrm{R}^{2}$ & 0.964 & 0.926 & 0.898 & 0.899 \\
Adj. $\mathrm{R}^{2}$ & 0.927 & 408 & 408 & 408 \\
Num. obs. & 408 & &
\end{tabular}

${ }^{* * *} \mathrm{p}<0.001,{ }^{* *} \mathrm{p}<0.01,{ }^{*} \mathrm{p}<0.05$ (Panel Newey-West standard errors)

The main coefficient of interest is the interaction term between Germany and the enactment of the reform $\left(\delta_{1}\right)$. The coefficient indicates that the German reform likely had a modest effect, at least relative to Austria. $\delta_{1}$ is negative and statistically significant throughout all regressions. The parallel trend assumption appears to hold because the time trend is not statistically significant (when we include industry output as a control).

\footnotetext{
96 Angrist \& Pischke 2009, p. 238.

${ }^{97}$ Newey and West 1987; Millo 2017. A Breusch-Godfrey test indicated autocorrelation for all regressions.
} 
The regressions would seem to suggest that the reform did in fact have a considerable impact in Germany (relative to Austria) between $59 \%$ and $65 \% .^{98}$ In absolute terms, the reduction is of course much smaller than the decrease in the two years between mid-2006 and 2008. This confirms Ringe’s argument that the English private limited company must have lost some of its significance for reasons other than the German reform. ${ }^{99}$ The reform seems to have simply resulted in an additional, smaller reduction of new firm formations of this type. While it is not a direct confirmation of Braun et al's results, this result is compatible with their finding of an increase in the formation of domestic German firms. ${ }^{100}$

\subsubsection{Belgium v. the Netherlands}

We can attempt a similar comparison for Belgium and the Netherlands, again using the Panel C timeline looking only at firms using an agent, and looking at the introduction of the SPRL$\mathrm{S}$ in Belgium as the reform to be tested. ${ }^{101}$ When we compare the monthly trends between these two countries, the difference appears greater than between Austria and Germany, even if the population sizes of the two countries are more similar. The number of incorporations in the UK by Dutch founders shot up in 2004 - likely the immediate impact of Inspire Art, peaking in 2006. This trend was not reflected in Belgium, which exhibited a peak only in 2009, after which there is a decline in both countries, which is more pronounced in Belgium than in the Netherlands.

\footnotetext{
${ }^{98}$ For example, $e^{-0.966}-1=-0.619$, which indicates an estimated reduction of $61.9 \%$.

99 Ringe 2013, p 257.

100 Braun et al 2013, pp 410, 412.

${ }^{101}$ See above section 2.3.
} 


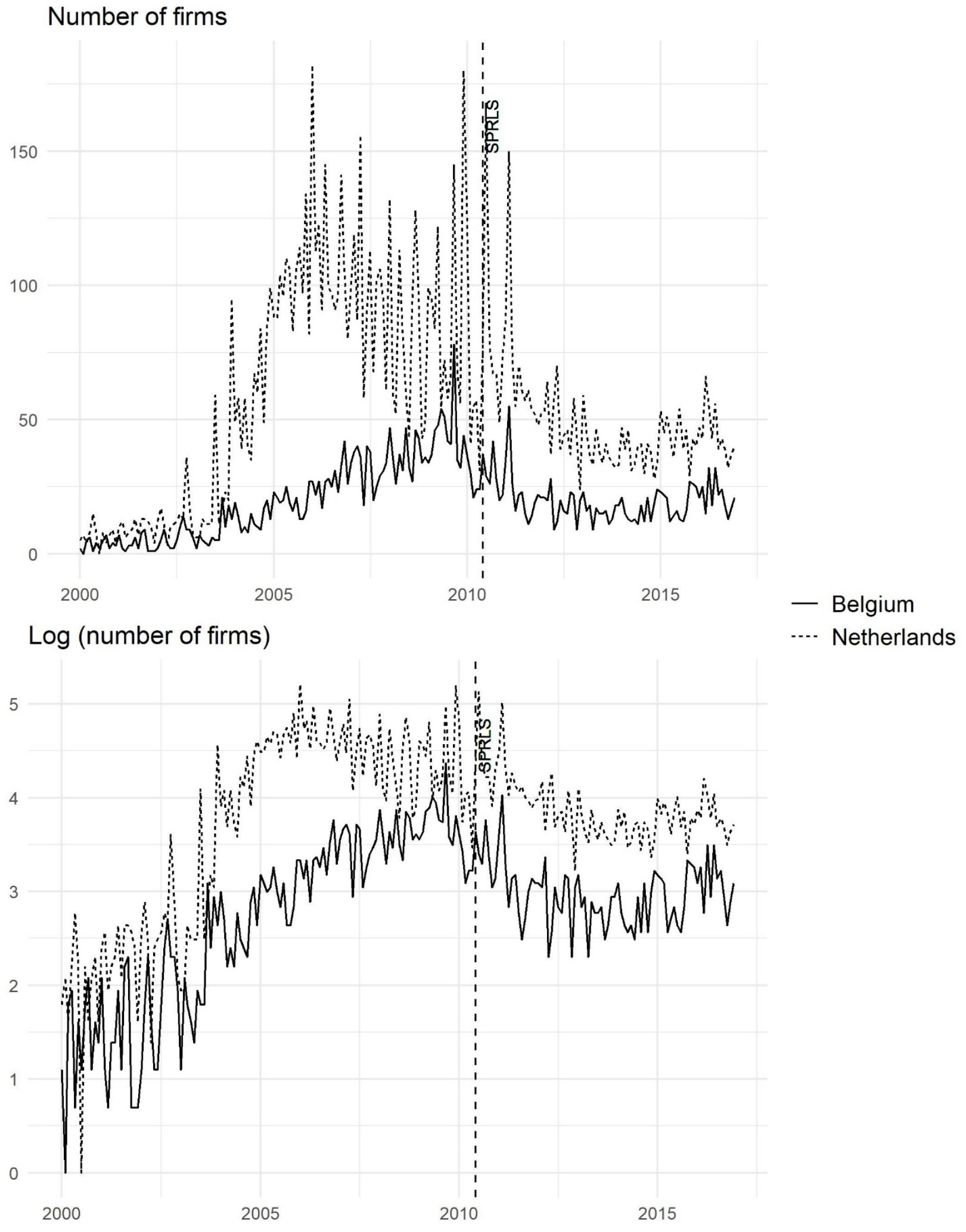

Figure 7: Monthly firm formations (>.5 directors/managers are citizens, incorporation agent) for Belgium and the Netherlands 
Figure 7 compares trends in Belgium and the Netherlands on an unmodified and a logarithmic scale. It appears that these two countries had different trends before the introduction of the SPRL-S in 2010, with the numbers in the Netherlands slightly declining, but still increasing in Belgium. Especially on the logarithmic scale, the trend in Belgium turns and subsequently parallels the one in the Netherlands around the time of the introduction of the SPRL-S. Table 2 reports a regression analogous to the one in the previous subsection.

$$
\begin{gathered}
\log \left(y_{i j}\right)=\alpha_{j} \cdot \text { month }_{j}+\beta \cdot \text { industry_output }_{i j}+\gamma_{1} \cdot \text { Belgium }+\gamma_{2} \cdot \text { post_SPRLS } \\
+\delta_{1}(\text { Belgium } \times \text { post_SPRLS })+\delta_{2}(\text { Belgium } \times \text { time })+\varepsilon_{i j}
\end{gathered}
$$

Table 2: Monthly regressions for Belgium/Netherlands

\begin{tabular}{lllll}
\hline & All citizens & & \multicolumn{2}{c}{$\begin{array}{l}\text { More than half are citizens \& } \\
\text { incorporation agent }\end{array}$} \\
\hline Industry output & $0.009^{*}$ & -0.000 & $0.012^{* *}$ & 0.001 \\
& $(0.004)$ & $(0.005)$ & $(0.004)$ & $(0.004)$ \\
Belgium & $-0.855^{* * *}$ & $-2.517^{* * *}$ & $-0.797^{* * *}$ & $-2.658^{* * *}$ \\
& $(0.072)$ & $(0.366)$ & $(0.069)$ & $(0.337)$ \\
Belgium* & -0.076 & $-0.476^{* * *}$ & -0.055 & $-0.503^{* * *}$ \\
post_SPRLS & $(0.073)$ & $(0.108)$ & $(0.072)$ & $(0.094)$ \\
Belgium*time & & $-0.007^{* * *}$ & & $-0.008^{* * *}$ \\
& & $(0.002)$ & & $(0.001)$ \\
Month fixed ef- & Yes & Yes & Yes & Yes \\
fects & & & 0.857 & 0.879 \\
$\mathrm{R}^{2}$ & 0.879 & 0.896 & 0.708 & 0.752 \\
Adj. $\mathrm{R}^{2}$ & 0.754 & 0.786 & 264 & 264 \\
Num. obs. & 264 & 264 &
\end{tabular}

${ }^{* * * *} \mathrm{p}<0.001,{ }^{* *} \mathrm{p}<0.01,{ }^{*} \mathrm{p}<0.05$ (Panel Newey-West standard errors)

The regressions in Table 2 are analogous to the ones performed for Austria and Germany above, but cover the period from 2006 through 2016. The key interaction variable Belgium*post_SPRLS is statistically significant only when we control for the country specific time trend (Belgium*time). The results here are consequently less robust than in the Germany/Austria 
comparison because they require us to account for differences in the trends between the two countries. Most likely, the company laws and traditional legal form choice patterns of the two countries were too different in the first place to provide for an ideal comparison. If anything, the reform may have helped to bring Belgian incorporation trends, which might otherwise have continued on a more upward trajectory, more in line with those in the Netherlands. In any event, the absolute numbers of firms are quite small and of little economic significance.

\section{Conclusion}

This article has explored the market for the incorporation of privately held firms in Europe and the US. Over the past 20 years since Centros, European legislatures have engaged in activity that may be considered "defensive regulatory competition," and may have had more or less legitimate reasons to do so. Overall, it appears that the option of setting up a private limited company in another Member State did not result in a permanent undermining of the regulatory authority over corporate law of any country. Against this backdrop, it is difficult to describe defensive regulatory competition as particularly well justified. Nevertheless, if we accept the goals of defensive regulatory competition, we have seen that at least the German one likely helped to further reduce the number of new private limited company formations in the UK by German founders. However, by the time of the enactment of the reform, the number had already decreased considerably for different reasons. Still, regulatory competition has resulted in legislative changes across the continent, in particular concerning the relationship between firms and their creditors. It has, most likely, accelerated the ongoing demise of the legal capital system.

\section{References}

- Adler B, Kahan M (2013) The Technology of Creditor Protection. University of Pennsylvania Law Review 161:1773-1814. 
- Anderson R (2018) The Delaware Trap: An Empirical Analysis of Incorporation Decisions. Southern California Law Review 2018:657-710.

- Angrist J, Pischke J (2009) Mostly Harmless Econometrics. Princeton University Press, Princeton.

- Armour J (2005) Who Should Make Corporate Law? EC Legislation versus Regulatory Competition. Current Legal Problems 58:370-413.

- Armour J (2006) Legal Capital: An Outdated Concept? European Business Organization Law Review 5-27.

- Ayres, I (1992) Judging Close Corporations in the Age of Statutes, Washington University Law Quarterly 70:365-397.

- Bartolacelli A (2016) The New Italian Almost Capital-less Private Companies: A Brand New Tile in the Mosaic. European Company and Financial Law Review 2016:665-707.

- Bartolacelli A (2017) Almost Capital-less Companies in Europe: Trends, Variations, Competition. European Company and Financial Law Review 2017:187-233.

- Barzuza M (2012) Market Segmentation: The Rise of Nevada as a Liability-Free Jurisdiction. Virginia Law Review 98:935-1000.

- Bebchuk L (1992) Federalism and the Corporation: The Desirable Limits on State Competition in Corporate Law. Harvard Law Review 105:1442-1510.

- Bebchuk L, Ferrell A (1999) Federalism and Corporate Law: The Race to Protect Managers from Takeovers. Columbia Law Review 99:1168-1199.

- Becht M, Enriques L, Korom V (2009) Centros and the Cost of Branching. Journal of Corporate Law Studies 9:171-199.

- Becht M, Mayer C, Wagner H (2008) Where do firms incorporate? Deregulation and the cost of entry. Journal of Corporate Finance 14:241-256.

- Birkmose H (2006) A 'Race to the Bottom' in the EU? Maastricht Journal of European and Comparative Law 13:35-80.

- Blanchflower D, Oswald A (1998) What Makes an Entrepreneur? Journal of Labor Economics 16:26-60.

- Bratton W (1994) Corporate Law's Race to Nowhere in Particular. University of Toronto Law Review 44:401-440.

- Braun R, Eidenmüller H, Engert A, Hornuf L (2013) Does Charter Competition Foster Entrepreneurship? A Difference-in-Difference Approach to European Company Law Reforms. Journal of Common Market Studies 51:399-415.

- Broughman B, Fried J, Ibrahim D (2014) Delaware Law as Lingua Franca: Theory and Evidence. Journal of Law and Economics 57:865-895. 
- Cary W (1974) Federalism and Corporate Law: Reflections Upon Delaware. Yale Law Journal 83:663-705.

- Dammann J (2004). Freedom of Choice in European Corporate Law, Yale Journal of International Law 29:477-544.

- Dammann J (2005) A New Approach to Corporate Choice of Law. Vanderbilt Journal of Transnational Law 38:51-107.

- Dammann J, Schündeln M (2011) The Incorporation Choices of Privately Held Corporations. Journal of Law, Economics and Organization 27:79-112.

- Dammann J, Schündeln M (2012) Where are Limited Liability Companies Formed? An Empirical Analysis. Journal of Law and Economics 55:741-791.

- Easterbrook F, Fischel D (1991) The Economic Structure of Corporate Law. Harvard University Press, Cambridge MA.

- Eldar, O (2019) Can Lax Corporate Law Increase Shareholder Value? Evidence from Nevada. Journal of Law and Economics 61:555-605.

- Enriques L (2004) EC Company Law and the Fears of a European Delaware. European Business Law Review 2004:1259-1274.

- Enriques L, Gelter M (2006) Regulatory Competition in European Company Law and Creditor Protection. European Business Organization Law Review 7:417-453.

- Enriques L, Gelter M (2007) How the Old World Encountered the New One: Regulatory Competition and Cooperation in European Corporate and Bankruptcy Law. Tulane Law Review 81:577-646.

- Enriques L, Macey J (2001) Creditors Versus Capital Formation: The Case Against the European Legal Capital Rules. Cornell Law Review 86: 1165-1204.

- Frankel T (1995) Fiduciary Duties as Default Rules. Oregon Law Review 74:1209-1277.

- Gelter M (2005) The Structure of Regulatory Competition in European Corporate Law. Journal of Corporate Law Studies 5:247-284.

- Gelter M (2017) Centros, the Freedom of Establishment for Companies and the Court's Accidental Vision for Corporate Law. In Nicola F, Davies B (eds): EU Law Stories. Contextual and Critical Histories of European Jurisprudence, Cambridge University Press, Cambridge, pp 309-337.

- Gelter M, Helleringer G (2018) Opportunity Makes a Thief: Corporate Opportunities as Legal Transplant and Convergence in Corporate Law. Berkeley Business Law Journal 18:92-153.

- Gelter M (work in progress) The Effects of Defensive Regulatory Competition and Minimum Capital: A Panel Analysis of Cross-Border Incorporations in Europe.

- Gelter M, Vicente L (forthcoming 2019) Abuse of Companies through Choice of Incorporation? In Birkmose H, Neville M, Sørensen K (eds): Abuse of Companies, Kluwer: Alphen aan den Rijn. 
- Gerner-Beuerle F, Mucciarelli F, Schuster E, Siems M (2018) Why do businesses incorporate in other EU Member States? An empirical analysis of the role of conflict of laws rules. International Review of Law and Economics 56:14-27.

- Gevurtz F (2012) Why Delaware LLCs? Oregon Law Review 91:57-127.

- Halabi S (2015) Veil-Piercing’s Procedure. Rutgers University Law Review 67:1001-1060.

- Halbhuber H (2001) National Doctrinal Structures and European Company Law. Common Market Law Review 38:1385-1420.

- Hopt K (2010) European Company and Financial Law: Observations on European Politics, Protectionism, and the Financial Crisis. In Bernitz U, Ringe W (eds): Company Law and Economic Protectionism, Oxford University Press, Oxford, pp. 13-31.

- Kahan M, Kamar E (2002) The Myth of State Competition in Corporate Law. Stanford Law Review 55:679-749.

- Kalss S (2015) Corporate Governance in Austria under the Influence of the European Union. Zeitschrift für vergleichende Rechtswissenschaft 114:157-191.

- Kane M, Rock E (2008) Corporate Taxation and International Charter Competition. Michigan Law Review 106:1229-1283.

Kobayashi B, Ribstein L (2011) Delaware for Small Fry: Jurisdictional Competition for Limited Liability Companies, University of Illinois Law Review 2011:91-144.

- Lennarts L (2017) Directors in the Twilight Zone - Kornhaas and "Beyond" - some Observations from a Dutch Perspective, in Gant J (ed) Harmonisation of European Insolvency Law, INSOL Europe, Nottingham, pp. 113-132.

- Manesh M (2017) Creatures of Contract: A Half-Truth about LLCSs. Delaware Journal of Corporate Law 42:391-465

- Millo G (2017) Robust Standard Error Estimators for Panel Models: A Unifying Approach. Journal of Statistical Software 82:1-27.

- Moisan (2015) A Look at the Publication Requirement in New York Limited Liability Company Law. Touro Law Review 31:465-476.

- Mülbert P, Birke, M (2002) Legal Capital - Is There a Case Against the European Legal Capital Rules? European Business Organization Law Review 3: 695-732.

- Newey W, West K (1987) A simple, positive semi-definite, heteroskedasticity and autocorrelation consistent covariance matrix. Econometrica 55:703-708.

- Pacces A (2016) Exit, voice and loyalty from the perspective of hedge funds activism in corporate governance. Erasmus Law Review 9:199-216.

- Reyes, F, Vermeulen E (2013) Company Law, Lawyers and "Legal” Innovation: Common Law versus Civil Law. Banking and Finance Law Review 28:433-474.

- Ribstein L (2005) Are Partners Fiduciaries? University of Illinois Law Review 2005:209-252. 
- Ribstein L, O’Hara E (2008) Corporations and the Market for Law. University of Illinois Law Review 2008:661-729.

- Rickford J (ed.) (2004) Reforming Capital. Report of the Interdisciplinary Group on Capital Maintenance, European Business Law Review 2004: 919-1027.

- Ringe W (2013) Corporate Mobility in the European Union - a Flash in the Pan? An empirical study on the success of lawmaking and regulatory competition. European Company and Financial Law Review 10:230-267.

- Ringe W (2017) Kornhaas and the Challenge of Applying Keck in Establishment. European Law Review 42:270-279.

- Roe M (2003). Delaware’s Competition. Harvard Law Review 117:588-646.

- Romano R (1992) State Competition for Close Corporation Charters: A Commentary. Washington University Law Quarterly 70:409-416.

- Romano R (1993) The Genius of American Corporate Law. AEI Press, Washington.

- Spamann H (2009) Contemporary Legal Transplants: Legal Families and the Diffusion of (Corporate) Law. Brigham Young University Law Review 2009:1813-1877.

- Tröger T (2005). Choice of Jurisdiction in European Corporate Law - Perspectives of European Corporate Governance. European Business Organization Law Review 6:3-64.

- van Stel A, Storey D, Thurik A (2007) The Effect of Business Regulations on Nascent and Young Business Entrepreneurship. Small Business Economics 28:171-186.

- Ventoruzzo M (2006). 'Cost-Based' and 'Rules-Based' Regulatory Competition: Markets for Corporate Charters in the U.S. and the E.U. NYU Journal of Law and Business 3:91-153 (2006).

- Winter R (1977) State Law, Shareholder Protection, and the Theory of the Corporation. Journal of Legal Studies 6:251-292.

- Winter R (1989) The ‘Race to the Top’ Revisited. Columbia Law Review 89:1526-1529.

- Zorzi A (2017) A European Nevada? Bad Enforcement as an Edge in State Competition for Incorporations. European Business Organization Law Review 18:251-272. 


\section{about ECGI}

The European Corporate Governance Institute has been established to improve corporate governance through fostering independent scientific research and related activities.

The ECGI will produce and disseminate high quality research while remaining close to the concerns and interests of corporate, financial and public policy makers. It will draw on the expertise of scholars from numerous countries and bring together a critical mass of expertise and interest to bear on this important subject.

The views expressed in this working paper are those of the authors, not those of the ECGI or its members. 
ECGI Working Paper Series in Law

Editorial Board

Editor Amir Licht, Professor of Law, Radzyner Law School, Interdisciplinary Center Herzliya

Consulting Editors John Coates, John F. Cogan, Jr. Professor of Law and Economics, Harvard Law School

Horst Eidenmüller, Freshfields Professor of Commercial Law, University of Oxford

Curtis Milhaupt, Professor of Law, Stanford Law School

Niamh Moloney, Professor of Law, Department of Law, London

School of Economics and Political Science

Editorial Assistants Alison Schultz, University of Mannheim

Julian Hanf, University of Mannheim

www.ecgi.global/content/working-papers 


\section{Electronic Access to the Working Paper Series}

The full set of ECGI working papers can be accessed through the Institute's Web-site (www.ecgi.global/content/working-papers) or SSRN:

Finance Paper Series http://www.ssrn.com/link/ECGI-Fin.html

Law Paper Series http://www.ssrn.com/link/ECGI-Law.html 